\title{
Determination of Volatile Organic Compounds and Antibacterial Activity of the Amazonian Cyanobacterium Synechococcus sp. Strain GFB01
}

\author{
Samuel Cavalcante do Amaral ${ }^{1}$, Agenor Valadares Santos ${ }^{1}{ }^{1}$, Maria Paula da Cruz Schneider ${ }^{2}$, \\ Joyce Kelly Rosário da Silva $1, *(\mathbb{B}$ and Luciana Pereira Xavier $1, * \mathbb{C}$ \\ 1 Laboratory of Biotechnology of Enzymes and Biotransformation, Biological Sciences Institute, \\ Federal University of Para, Belém 66075-110, Brazil; samuel.amaral@icb.ufpa.br (S.C.d.A.); \\ valadaresantos@gmail.com (A.V.S.) \\ 2 Center of Genomics and Systems Biology, Biological Sciences Institute, Federal University of Para, \\ Belém 66075-110, Brazil; mariapaulacruzschneider@gmail.com \\ * Correspondence: joycekellys@ufpa.br (J.K.R.d.S.); luxavier@gmail.com (L.P.X.); \\ Tel.: +55-91-3201-8426 (J.K.R.d.S.)
}

Academic Editor: Tatsufumi Okino

Received: 22 August 2020; Accepted: 15 September 2020; Published: 16 October 2020

\begin{abstract}
Cyanobacteria exhibit great biotechnological potential due to their capacity to produce compounds with various applicability. Volatile organic compounds (VOCs) possess low molecular weight and high vapor pressure. Many volatiles produced by microorganisms have biotechnological potential, including antimicrobial activity. This study aimed to investigate the VOCs synthesized by cyanobacterium Synechococcus sp. strain GFB01, and the influence of nitrate and phosphate on its antibacterial potential. The strain was isolated from the surface of the freshwater lagoon Lagoa dos Índios, Amapá state, in Northern Brazil. After cultivation, the VOCs were extracted by a simultaneous distillation-extraction process, using a Likens-Nickerson apparatus $(2 \mathrm{~h})$, and then identified by GC-MS. The extracts did not display inhibitory activity against the Gram-positive bacteria tested by the disk-diffusion agar method. However, the anti-Salmonella property in both extracts (methanol and aqueous) was detected. The main VOCs identified were heptadecane $(81.32 \%)$ and octadecyl acetate $(11.71 \%)$. To the best of our knowledge, this is the first study of VOCs emitted by a cyanobacterium from the Amazon that reports the occurrence of 6-pentadecanol and octadecyl acetate in cyanobacteria.
\end{abstract}

Keywords: cyanobacteria; Synechococcus sp.; volatiles organic compounds; 6-pentadecanol; octadecyl acetate

\section{Introduction}

Cyanobacteria are the most ancient group of photosynthetic bacteria of earth, and its presence contributed to the development of aerobic atmospheric in which allowed the appearance of new forms of life [1]. Moreover, it is known that they gave rise to the higher plant chloroplasts. Plant and cyanobacteria, therefore, possess several similarities [2]. These bacteria belong to a very diverse group distributed in several types of environments, including hot spring, cold deserts, oceans, hypersaline water, and freshwater [3,4]. The capacity to survive in various distinct habitats is due to its adaptive mechanisms, such as their ability to produce secondary metabolites with a large assortment of functions and structures $[5,6]$. In the literature, a considerable number of molecules identified in cyanobacteria with potential applications in pharmaceutical, food, and cosmetic industries, as well as biofuel and agriculture, have been described [7]. 
The quantity of bacteria resistant to antibiotics has expressively increased, leading to great concern among the members of the scientific community [8,9]. In this context, many types of research have been developed in order to discover new antibiotic compounds from distinct sources [10-12]. Cyanobacteria are considered to be a promising source of antibacterial compounds whose mechanism of action is very variable $[13,14]$. Many studies have mainly focused only on the evaluation of the activity of extracts, and there are few investigations to analyze the influence of nutrient input on the antagonist activity against pathogenic bacteria [15-17]. Phosphate and nitrate are essential nutrients in cyanobacteria metabolism. Their concentrations in the culture medium substantially affect the growth and the secondary metabolite profile of cyanobacteria [18,19].

Recently, a category of compounds produced by cyanobacteria has gained attention: the volatile organic compounds (VOCs) [20]. These compounds are produced and released into the environment by other types of bacteria, fungi, and plants. They are known for usually having a low molecular weight and high vapor pressure. Thus, they can quickly evaporate and migrate to the atmosphere [21]. The function of VOCs in cyanobacteria is still poorly understood. However, different biological roles are attributed to them, such as protection against bacterivores or other cyanobacteria, homeostasis and maintenance, preventing dehydration, cold-stress response, and signaling [22]. VOCs found in cyanobacteria can be classified into several chemical classes, such as terpenoids, fatty acid derivatives, amino acid derivatives, carbohydrate derivatives, and nor-terpenoids pathway products [23].

Geosmin and 2-methylborneol are some of the most frequent volatile compounds produced by cyanobacteria, which are "off-flavor" compounds associated with fouling taste and odor problems in drinking water and fish [24,25]. Cyanobacteria are a rich source of volatile metabolites that can be applied in several fields. Some of these compounds have shown antibacterial, anticancer, anti-cyanobacterial, antifungal, antioxidant, and anti-inflammatory activity [26-30]. In addition, cyanobacteria are capable of producing alkanes and alkenes by using fatty acid as substrates. Hydrocarbons and other volatiles compounds can be applied in the production of biofuel and fragrances, respectively [31,32].

The availability of nitrogen, carbon, sulfur, and phosphorus, as well as various environmental factors, such as illumination, $\mathrm{pH}$ value, temperature, and growth phase, can influence the chemical composition of cyanobacteria [33]. A study of cyanobacterium collected from a peculiar environment of the Amazon can provide the identification of unfamiliar VOCs and their biological potential. Thus, this work aimed at the identification and evaluation of the biotechnological potential of VOCs synthesized by freshwater cyanobacterium Synechococcus sp. strain GFB01 (Figure 1) from the Amazon region (Brazil). Synechococcus species are described as fast-growing unicellular organisms that are very abundant in the ocean and extremely relevant to the primary biomass production [4,34]. Due to their amenability to genetic manipulation, they have been used as a model organism to investigate pathways involved in the synthesis of secondary metabolites, as well as cell factories to produce commercially relevant molecules [35,36].
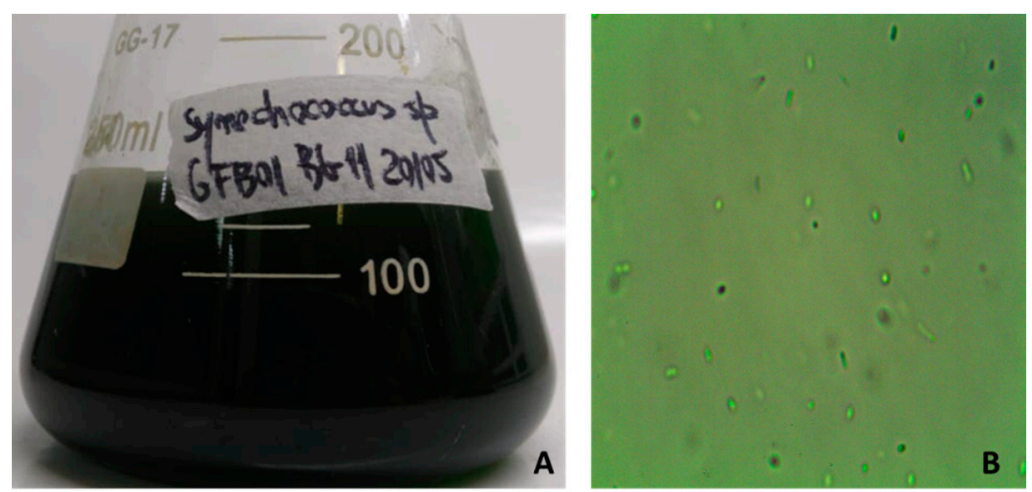

Figure 1. Synechococcus sp. GFB01 in BG11 medium (A) and visualized by optical microscope (B). Magnification: 1000× (Nikon H550L). 


\section{Results}

Figure 2 represents the chromatogram obtained by GC-MS analysis of the volatile fraction of Synechococcus sp. GFB01. Heptadecane was the main compound identified, followed by octadecyl acetate (Table 1).

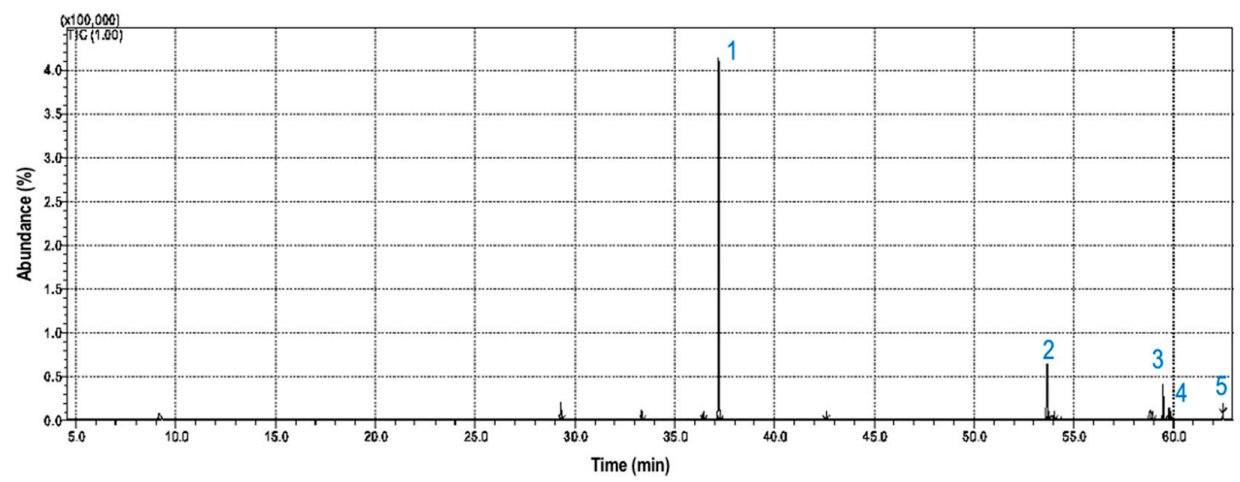

Figure 2. Ion chromatogram of GC-MS analysis of volatile fraction of Synechococcus sp. strain GFB01: (1) heptadecane, (2) octadecyl acetate, (3) pentadecane, (4) hexadecane, and (5) 6-pentadecanol.

Table 1. Volatile organic compounds of Synechococcus sp. strain GFB01.

\begin{tabular}{cccc}
\hline Compound $^{\mathbf{a}}$ & RI Calculated $^{\mathbf{b}}$ & RI Literature $^{\mathbf{c}}$ & Relative Abundance (\%) $^{\text {R }^{*}}$ \\
\hline Pentadecane & 1507 & 1500 & 3.75 \\
Hexadecane & 1609 & 1600 & 2.21 \\
6-Pentadecanol & 1685 & 1675 & 1.01 \\
Heptadecane & 1707 & 1700 & 81.32 \\
Octadecyl acetate & 2222 & 2209 & 11.71 \\
\hline
\end{tabular}

${ }^{a}$ Compound identified, ${ }^{\mathrm{b}}$ retention index experimentally obtained, and ${ }^{\mathrm{c}}$ retention index from literature.

Regarding the antibacterial assay, the extracts did not display inhibitory activity against the Gram-positive bacteria here tested. However, Salmonella typhimurium ATCC 14021 (American type culture collection, Rockville, MD, USA) had its growth inhibited by all samples except for extract BG11N+ varying from $7.6 \pm 0.9$ to $9.8 \pm 0.6 \mathrm{~mm}$. Lipophilic extracts exhibited higher antibacterial effects in comparison to hydrophilic extract. Nonetheless, these differences between the groups were not statically significant. Disks treated only with $0.1 \mathrm{M}$ Tris-HCl buffer $\mathrm{pH} 7.1$ or methanol (100\%) did not show any antagonist activity (Figure 3).

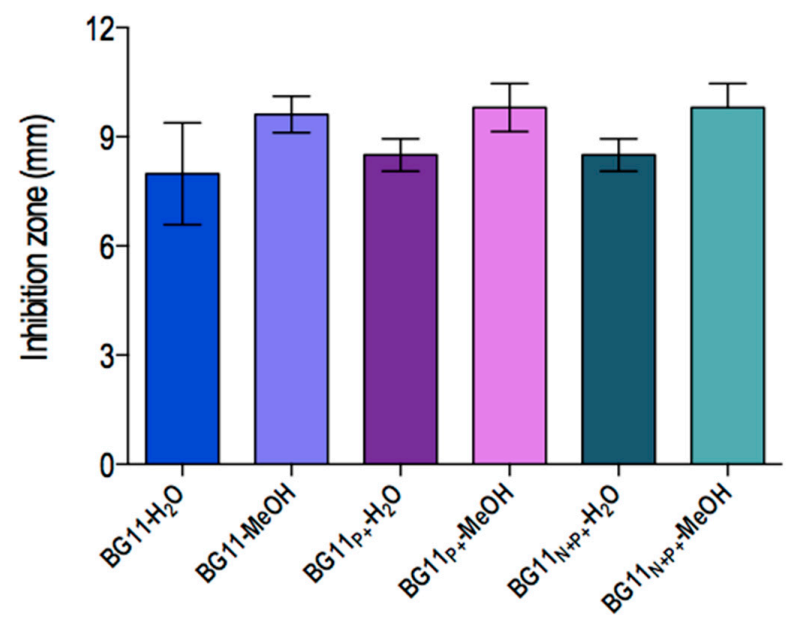

Figure 3. Antibacterial activity of Synechococcus sp. strain GFB01 extracts obtained from culture in different phosphate and nitrate concentrations against the Gram-negative bacterium Salmonella typhimurium ATCC 14021. The paper disk diameter was included. 


\section{Discussion}

Heptadecane was the most abundant in the volatile fraction of Synechococcus sp. strain GFB01, and branched-chain alkanes were absent. Previous studies reported a strong relation between alkane chain length and cyanobacterial natural habitat. Heptadecane and pentadecane are related as the main compounds in cyanobacteria from freshwater and marine environments, respectively [37]. Moreover, studies suggested a relationship between morphological aspects and hydrocarbons' profile to cyanobacteria. Branched-chain alkanes were detected only in filamentous cyanobacteria but very rare in unicellular strain. This distinct characteristic can be attributed to the fatty acid utilized as a precursor in the alkane synthesis or to the substrate specificity of enzymes involved in the addition of branches [38].

Cyanobacteria are one of the most important producers of alkanes in the ocean [39]. The genera Prochlorococcus and Synechococcus are estimated to release between 308 and 771 million tons of hydrocarbons per year [39]. Oil-degrading bacteria are capable of using these hydrocarbons and converting them to carbon dioxide, playing an essential role in the maintenance of these microorganisms [40]. The physiological role of hydrocarbons in cyanobacteria is unclear. However, in specific environmental conditions, the production of individual alkanes is enhanced [41].

Synechocystis sp. PCC 6803 strain cultivated at $20^{\circ} \mathrm{C}$ displayed a substantial increase of heptadecane, which plays an essential role in cold tolerance [41]. In lagoon Lagoa dos Índios, the average temperature is between 23 and $30^{\circ} \mathrm{C}$ [42]. This alteration may cause modifications in cell metabolism, including the heptadecane production level in Synechococcus sp. GFB01. The concentration of hydrocarbons in cyanobacteria is predominantly in the thylakoid and cytoplasmic membranes. In both layers, they are responsible for increasing flexibility and facilitating the curvature during cell growth. Non-hydrocarbon-producing genetically manipulated cyanobacteria exhibited a larger size when compared to the wild type. The absence of hydrocarbon also negatively affected cell growth and caused cell damage [43].

There are two known biosynthetic pathways for the production of hydrocarbon in cyanobacteria, which have never been detected simultaneously in the same organism [31]. Fatty acids are used as a common substrate for both pathways: One pathway is predominant and characterized by the conversion of fatty acyl-ACP to fatty acyl aldehyde and its posterior transformation into alkane by enzymes acyl-acyl carrier protein reductase (AAR) and aldehyde reformulating oxygenase (ADO), respectively $[31,44]$. The second pathway origins the $\alpha$-olefins (OLS) by a large multidomain protein with homology to type I polyketide synthase $[45,46]$. The non-coexistence of the FAAR/ADO and OLS pathway suggests the action of selective pressure, which preserved a route while excluding others [31]. The chemical profile of VOCs identified in this study is associated with the AAR/ADO pathway, since heptadecane and pentadecane are found exclusively in cyanobacteria encoding these enzymes [31].

Alkanes here identified are very useful in the chemical industry as major constituents of various fuels, such as diesel, jet flew, and gasoline [47]. The VOCS produced by cyanobacterium Spirulina platensis showed antibacterial activity against Gram-positive and Gram-negative bacteria. Its major constituent was heptadecane [48]. Moreover, this compound exhibits the capacity of downregulating some metabolites related to the inflammatory process by activation of NF-kappaB transcription factor which persistently occurs in a considerable number of diseases, such as cancer, neurodegenerative disease, and asthma [30].

Octadecyl acetate was identified in other organisms, such as moths and bees, in their extracts of the sex pheromone gland and Dufour's gland, respectively [49-51]. In addition, this component is present in the defensive secretion with repellent propriety of certain arthropods [52-54]. Moreover, in the females of Eupoecilia ambiguella (grape moth pest), it is responsible for increasing the capacity of attracting males when combined with (Z)-9-dodecenyl acetate and dodecyl acetate [52]. Besides, octadecyl acetate has been reported in the leaves, roots, and flowers of plants with medicinal and commercial value, including strawberries, galanga, rough lemon, potatoes, and pequi [55-59]. Dracocephalum moldavica, 
a medicinal plant whose essential oil has antiseptic and antibacterial properties, emitted this volatile after the exposure to salt stress, suggesting a protective role [60,61]. In the industry, the octadecyl acetate is very useful to produce shampoo, deodorants, candles, hairspray cream, and rinse, due to its low toxicity and lack of allergic response $[62,63]$.

An unidentified C-15 aliphatic alcohol was found in a cyanobacterial mat by Rejmankova and co-workers [64]. This compound behaved as an attractive biological agent for Anopheles mosquitoes. The lagoon Lagoa dos Índios is regionally known as a hangover area characterized by a complex and peculiar environment with a great variety of species. Many organisms utilize this ecosystem only for shelter and breeding. Its natural conditions are favorable for the development of various species of Culicidae, mainly immature mosquitoes belonging to the genus Anopheles [65]. Based on the above-cited study, there is a possibility that 6-pentadecanol contributes to the high incidence of the Anopheles, including some vector of diseases, such as malaria, in this region. Further research will be relevant to better clarify this issue, and it may contribute to the prevention and control of these mosquitoes.

The chemical compound 6-pentadecanol is a fatty alcohol, a compound class that contains a significant number of applications in the cosmetic, pharmaceutical, and chemical industries [66]. Due to its lubricating, emollient, solubilizing, or emulsifying properties, these compounds can be used as biofuel additives [67]. In addition, long-chain aliphatic alcohols, comprising between six and twenty-two carbons atoms, exhibit low toxicity [68]. Some fatty alcohols showed inhibition of the growth of follicular bacterium Propionibacterium acnes responsible for inducing acne and inflammation [69]. The presence of hydrophilic and hydrophobic regions in these molecules contributes to its antimicrobial activity. Moreover, they have been used as a precursor of bioactive molecules such as pachastrissamine and Commiphoru mukul (guggul), which present cytotoxicity against human lung carcinoma cells and anti-inflammatory properties, respectively [70,71].

Cyanobacteria exhibit a high ability to produce important fatty alcohols through the use of metabolic engineering due to its photosynthetic capability and for being genetically manipulable [72,73]. Moreover, advances in DNA sequencing technology have favored the deposit of various cyanobacterial genomes in a short period and have allowed a greater understanding of their genetic systems [74]. The production of 6-pentadecanol in this cyanobacterium suggested the existence of an alcohol dehydrogenase able to reduce fatty aldehyde intermediate to fatty alcohol. NCBI search reveled a medium chain zinc-binding alcohol dehydrogenase family protein in the genome of Synechococcus sp. GFB01 (accession number: WP_048017391). Homologous protein was found by BLAST-protein on NCBI. This enzyme exhibits high similarity with other zinc-binding alcohol dehydrogenase belonged not solely to cyanobacteria, but also to other microorganisms. Zinc-binding alcohol dehydrogenase family requires zinc atom(s) as cofactor and can be encountered in mammals, plants, fungi, and bacteria [75]. They accomplish an enormous variety of functions in cell metabolism, including ethanol generation by Saccharomyces cerevisiae [76].

Some cyanobacteria isolated from Amazon have been considered as a promising source of biodiesel due to their fatty acid profile $[77,78]$. The alcohol 6-pentadecanol was identified in lesser quantity than heptadecane, which leads to inferring that acyl-ACP reductase action converted the most of fatty aldehydes generated to alkanes. There is little knowledge about alcohol dehydrogenases produced by cyanobacteria. However, its activity is induced by stress conditions [79]. Biochemical characterization of WP_048017391 would reveal its substrate affinity and also whether it preferably reduces aldehyde or oxidize alcohols. The cyanobacterium Synechococcus elongatus PCC 7942 was capable of producing fatty alcohol to generate wax ester. The incorporated biosynthetic pathway was formed by the co-expression of long-chain alcohol dehydrogenase and an acyl-ACP reductase from Synechocystis sp. PCC 6803, along with diacylglycerol acyltransferase [80].

The investigation of the antibacterial activity of cyanobacteria is mainly focused on filamentous species. However, few studies have been conducted on the bactericidal property of species from Chroococcales group in which include the genera Synechocystis and Synechococcus [81]. 
These compounds play a crucial ecological role by preventing the colonization of pathogenic bacteria in the mucilaginous sheath [14]. Gram-positive bacteria are usually the main target of antibiotic compounds from cyanobacteria [82,83]. In our study, the extracts of Synechococcus sp. GFB01 did not display inhibition against any Gram-positive bacteria. Therefore, these results indicate a different action mechanism in comparison to other substances found in these microorganisms.

Gram-negative bacteria have greater resistance to antibiotics due to their outer membrane composed of lipopolysaccharide (LPS), which impedes the entrance of these compounds inside the cell [82]. This membrane acts as a selective barrier where small hydrophilic antibiotics utilize the pore-forming porins to access the cell interior while hydrophobic molecules diffuse across the lipid bilayer [83]. The anti-Salmonella activity was detected in both aqueous and methanolic extract. Methanol is a solvent widely utilized during bioactive compounds extraction due to its amphiphilic nature, as well as being capable of dissolving non-polar compounds. Thus, there is the possibility of inhibitory compound with distinct action mechanism in Synechococcus sp. strain GFB01.

Comprehending factors involved in the production of bioactive compounds can provide insight into their functions in the cell and help optimize production for a particular substance commercially interesting. Nitrate and phosphate are essential elements for all types of cells, and few studies reported the effect of their concentrations on cyanobacterial antibiotic compounds [17]. In the study with Synechococcus sp. GFB01, the increase of nitrate concentration suppressed the antibacterial effect against Salmonella typhimurium ATCC 14021. It is known that phosphate is involved in the biosynthesis of many different types of antibiotics and a more significant number of other secondary metabolites, being recognized by its suppressor role [84]. In contrast, in this study, the supplementation with this element did not affect the inhibitory property of cyanobacterium. However, it was capable of reversing the suppressor role caused by enrichment with nitrate.

\section{Materials and Methods}

\subsection{Strain and Culture Conditions}

The cyanobacterium Synechococcus sp. GFB01 was selected from the culture collection of Center of Genomics and Systems Biology at Biological Sciences Institute, Federal University of Pará (Belém, Brazil). The strain was collected in 2011 from the surface of the freshwater lagoon Lagoa dos Índios, Macapá, Amapá State, Northern Brazil ( $\left.0^{\circ} 01^{\prime} 55.1^{\prime \prime} \mathrm{N} 51^{\circ} 06^{\prime} 09.6^{\prime \prime} \mathrm{W}\right)$. This strain was the first of this genus isolated from South America to have its genome sequenced [85]. Cyanobacteria were grown photoautotrophically at a constant temperature of $25^{\circ} \mathrm{C}$, with controlled light conditions (12 h of light and $12 \mathrm{~h}$ of darkness) in BG-11 medium [86]. Modified BG11 medium was utilized to investigate the nitrate and phosphate influence on antibacterial property of Synechococcus sp. GFB01. In the first medium was added two-fold nitrate concentration $(3.0 \mathrm{~g} / \mathrm{L})\left(\mathrm{BG} 11_{\mathrm{N}+}\right)$, while the second was supplemented with three-fold phosphate concentration $(0.12 \mathrm{~g} / \mathrm{L})\left(\mathrm{BG} 11_{\mathrm{P}+}\right)$. The third medium showed both nitrate and phosphate concentration previously described $\left(\mathrm{BG}_{\mathrm{N}+\mathrm{N}+\mathrm{P}+}\right)$.

\subsection{Biomass Harvesting}

The cyanobacterial cells were harvested from $1 \mathrm{~L}$ culture by centrifugation at $6000 \times g$ for $25 \mathrm{~min}$. The supernatant was recovered and filtrated and tested for antibacterial activity, while the wet biomass was distributed in falcon-tube and frozen at $-20^{\circ} \mathrm{C}$, until use.

\subsection{Cyanobacterial Extract}

The supernatant was frozen at $-80{ }^{\circ} \mathrm{C}$, freeze-dried, and then stored at $-20{ }^{\circ} \mathrm{C}$. The lyophilized material was resuspended in $0.1 \mathrm{M}$ Tris- $\mathrm{HCl}$ buffer $\mathrm{pH} 7.1$ to a final concentration of $50 \mathrm{mg} / \mathrm{mL}$. The mixture was vigorously homogenized with vortex for $30 \mathrm{~s}$ and subsequently centrifuged at $12,000 \times g$ for $10 \mathrm{~min}$, to obtain an aqueous extract. To the pellet was added $1 \mathrm{~mL}$ of methanol, and then 
it was vortexed and centrifuged at the same conditions. The supernatant was collected and used as methanolic extract.

\subsection{Antibacterial Assay}

The antibacterial activity of extracts was determined by using paper disk diffusion method. Four bacterial strains were utilized as organism test: Bacillus subtilis ATCC 6633, Salmonella typhimurium ATCC 14021, Corynebacterium fimi NTCS 7547, and Listeria monocytogenes ATCC 6477. These bacteria were cultivated in $10 \mathrm{~mL}$ of LB medium, at $37^{\circ} \mathrm{C}$, for $24 \mathrm{~h}$. Then, $100 \mu \mathrm{L}$ of bacterial culture was mixed with $25 \mathrm{~mL}$ of BHI agar medium (Liofilchem, Roseto Degli Abruzzi, Italy)) at $46^{\circ} \mathrm{C}$ and then poured into a Petri dish. Paper discs were treated with $25 \mu \mathrm{L}$ of extract and were left to dry for two hours. Paper discs (6 mm) impregnated with methanolic (99.8\%, Vetec Química Fina, Rio de Janeiro, Brazil) extract were stored at $70{ }^{\circ} \mathrm{C}$, to allow methanol evaporation. The discs were placed on the agar surface and incubated at $37^{\circ} \mathrm{C}$ for $24 \mathrm{~h}$.

\subsection{Volatile Organic Compounds Extraction}

The volatile organic compounds were extracted by simultaneous hydrodistillation-extraction. A Likens and Nickerson apparatus was used with n-pentane as organic solvent. This process was carried out for $2 \mathrm{~h}$ with $3 \mathrm{~g}$ of cyanobacterial wet biomass diluted in $250 \mathrm{~mL}$ of distillated water.

\subsection{Gas Chromatography/Mass Spectrometry Analysis (GC/MS)}

The volatile organic compounds were analyzed by GC/MS (EI, $70 \mathrm{eV}$ ) on a Shimadzu QP 2010 plus instrument (Shimadzu Corporation, Tokyo, Japan) equipped with an Rtx-5MS silica capillary column (30 $\mathrm{m} \times 0.25 \mathrm{~mm} ; 0.25 \mu \mathrm{m}$ film thickness, Restek Corporation, Bellefonte, PA, USA). Helium was used as carrier gas, adjusted to a linear velocity of $1 \mathrm{~mL} / \mathrm{min}$ (measured at $100{ }^{\circ} \mathrm{C}$ ). The column temperature was from 60 to $240{ }^{\circ} \mathrm{C}$, with an increase at a rate of $3{ }^{\circ} \mathrm{C} / \mathrm{min}$. The injection type used was splitless ( $2 \mathrm{~mL}$ of a 1:1000 hexane solution) with of $250{ }^{\circ} \mathrm{C}$. The temperature of the ion source and connection parts was maintained at $200{ }^{\circ} \mathrm{C}$. Volatile constituents were determined by comparison of mass fragmentation patterns and molecular weight to authentic standards found in the NIST (National Institute of Standards and Technology,) mass spectral library (Gaithersburg, MD, USA). The retention index was calculated for each compound, using a homologous series of $n$-alkanes (C8-C32, Sigma-Aldrich, Milwaukee, WI, USA) [87].

\subsection{Statistical Analysis}

The antibacterial experiments were performed in triplicate and expressed as means \pm standard deviation. Analysis of variance was conducted by Tukey test, following one-way ANOVA; differences at $p<0.05$ were considered statistically significant, using the software GraphPad 6.0 (GraphPad Software, San Diego, CA, USA, https://www.graphpad.com/).

\section{Conclusions}

The work revealed five volatile organic compounds in Synechococcus sp. GFB01. The volatile profile analysis showed the presence of compounds that have never been described for this phylum: 6-pentadecanol and octadecyl acetate. Both are well described in the literature due to their biotechnological potential. However, their contribution to the environment and physiological role has not yet been studied for this group of microorganisms. There is also little information about the genes involved in its biosynthesis. Further studies based on genomics can be used to gain a better understanding about the biosynthetic pathway for the production of these compounds, since its genome sequence is available in NCBI, under accession number NZ_LFEK00000000.1. The studied strain was capable of inhibiting Salmonella typhimurium ATCC 14021 growth. By changing phosphate and nitrate concentrations in the medium, it was possible to observe different levels of activity, but not 
significant. An exception was observed for extract obtained from cells cultivated in medium solely enriched with nitrate, where the activity was abolished.

Author Contributions: L.P.X. and J.K.R.d.S. conceived of the experiments and analyzed the data. M.P.d.C.S. was responsible for the cultivation and maintenance of the cyanobacteria strains. A.V.S. gave assistance during the execution of experiments. S.C.d.A. performed the assays and analyzed the data. S.C.d.A., L.P.X. and J.K.R.d.S. wrote the manuscript. All authors have read and agreed to the published version of the manuscript.

Funding: This research received no external funding.

Acknowledgments: This work has been supported by grants from the National Council for Scientific and Technological Development (CNPq), from the Foundation for Supporting Research in the State of Pará (FAPESPA), and from Coordination for the Improvement of Higher Level Personnel (CAPES).

Conflicts of Interest: The authors declare no conflict of interest.

\section{References}

1. Kulasooriya, S. Cyanobacteria: Pioneers of Planet Earth. Ceylon J. Sci. (Biol. Sci.) 2012, 40, 71. [CrossRef]

2. Martin, W.; Stoebe, B.; Goremykin, V.; Hapsmann, S.; Hasegawa, M.; Kowallik, K.V. Gene transfer to the nucleus and the evolution of chloroplasts. Nature 1998, 393, 162-165. [CrossRef] [PubMed]

3. Drobac-Cik, A.; Dulic, T.; Stojanovic, D.; Svircev, Z. The importance of extremophile cyanobacteria in the production of biologically active compounds. Zb. Matice Srp. Prir. Nauk. 2007, 57-66. [CrossRef]

4. Zwirglmaier, K.; Jardillier, L.; Ostrowski, M.; Mazard, S.; Garczarek, L.; Vaulot, D.; Not, F.; Massana, R.; Ulloa, O.; Scanlan, D.J. Global phylogeography of marine Synechococcus and Prochlorococcus reveals a distinct partitioning of lineages among oceanic biomes. Environ. Microbiol. 2007, 10, 147-161. [CrossRef] [PubMed]

5. Beck, C.; Knoop, H.; Axmann, I.M.; Steuer, R. The diversity of cyanobacterial metabolism: Genome analysis of multiple phototrophic microorganisms. BMC Genom. 2012, 13, 56. [CrossRef] [PubMed]

6. Borowitzka, M.A. High-value products from microalgae-Their development and commercialization. J. Appl. Phycol. 2013, 25, 743-756. [CrossRef]

7. Abed, R.M.M.; Dobretsov, S.; Sudesh, K. Applications of cyanobacteria in biotechnology. J. Appl. Microbiol. 2009, 106, 1-12. [CrossRef]

8. Hernández, F.; Calısto-Ulloa, N.; Gómez-Fuentes, C.; Gómez, M.; Ferrer, J.; González-Rocha, G.; Bello-Toledo, H.; Botero-Coy, A.M.; Borx, C.; Ibáñez, M.; et al. Occurrence of antibiotics and bacterial resistance in wastewater and sea water from the Antarctic. J. Hazard. Mater. 2019, 363, 447-456. [CrossRef]

9. Qiao, M.; Ying, G.-G.; Singer, A.C.; Zhu, Y.-G. Review of antibiotic resistance in China and its environment. Environ. Int. 2018, 110, 160-172. [CrossRef]

10. Bonifácio, B.V.; dos Santos Ramos, M.A.; da Silva, P.B.; Bauab, T.M. Antimicrobial activity of natural products against Helicobacter pylori: A review. Ann. Clin. Microbiol. Antimicrob. 2014, 13, 54.

11. Barbieri, R.; Coppo, E.; Marchese, A.; Daglia, M.; Sobarzo-Sánchez, E.; Nabavi, S.F.; Nabavi, S.M. Phytochemicals for human disease: An update on plant-derived compounds antibacterial activity. Microbiol. Res. 2017, 196, 44-68. [CrossRef] [PubMed]

12. Mishra, V.K.; Passari, A.K.; Chandra, P.; Leo, V.V.; Kumar, B.; Uthandi, S.; Thankappan, S.; Gupta, V.K.; Singh, B.P. Determination and production of antimicrobial compounds by Aspergillus clavatonanicus strain MJ31, an endophytic fungus from Mirabilis jalapa L. using UPLC-ESI-MS/MS and TD-GC-MS analysis. PLOS ONE 2017, 12, e0186234.

13. Falaise, C.; François, C.; Travers, M.-A.; Morga, B.; Haure, J.; Tremblay, R.; Turcotte, F.; Pasetto, P.; Gastineau, R.; Hardivillier, Y.; et al. Antimicrobial Compounds from Eukaryotic Microalgae against Human Pathogens and Diseases in Aquaculture. Mar. Drugs 2016, 14, 159. [CrossRef] [PubMed]

14. Rao, R. Antimicrobial Activity of Cyanobacteria. Indian J. Mar. Sci. 1994, 33, 55-56.

15. Soltani, N.; Khavari-Nejad, R.A.; Tabatabaei Yazdi, M.; Shokravi, S.; Fernández-Valiente, E. Screening of Soil Cyanobacteria for Antifungal and Antibacterial Activity. Pharm. Biol. 2005, 43, 455-459. [CrossRef]

16. Shaieb, F.A.; Issa, A.A.-S.; Meragaa, A. Antimicrobial activity of crude extracts of cyanobacteria Nostoc commune and Spirulina platensis. Arch. Biomed. Sci. 2014, 2, 34-41.

17. El Semary, N.A. The antimicrobial profile of extracts of a Phormidium-like cyanobacterium changes with phosphate levels. World J. Microbiol. Biotechnol. 2012, 28, 585-593. [CrossRef] 
18. Kuffner, I.; Paul, V. Effects of nitrate, phosphate and iron on the growth of macroalgae and benthic cyanobacteria from Cocos Lagoon, Guam. Mar. Ecol. Prog. Ser. 2001, 222, 63-72. [CrossRef]

19. Harris, T.; Smith, V.; Graham, J.; Van de Waal, D.; Tedesco, L.; Clercin, N. Combined effects of nitrogen to phosphorus and nitrate to ammonia ratios on cyanobacterial metabolite concentrations in eutrophic Midwestern USA reservoirs. Inland Waters 2016, 6, 199-210. [CrossRef]

20. Milovanović, I.; Mišan, A.; Simeunović, J.; Kovač, D.; Jambrec, D.; Mandić, A. Determination of Volatile Organic Compounds in Selected Strains of Cyanobacteria. J. Chem. 2015, 2015, 969542. [CrossRef]

21. Rowan, D.D. Volatile Metabolites. Metabolites 2011, 1, 41-63. [CrossRef] [PubMed]

22. Fink, P. Ecological functions of volatile organic compounds in aquatic systems. Mar. Freshw. Behav. Physiol. 2007, 40, 155-168. [CrossRef]

23. Santos, A.B.; Fernandes, A.S.; Wagner, R.; Jacob-Lopes, E.; Zepka, L.Q. Biogeneration of volatile organic compounds produced by Phormidium autumnale in heterotrophic bioreactor. J. Appl. Phycol. 2016, 28, 1561-1570. [CrossRef]

24. Ludwig, F.; Medger, A.; Bornick, H.; Opitz, M.; Lang, K.; Gottfert, M.; Roske, I. Identification and Expression Analyses of Putative Sesquiterpene Synthase Genes in Phormidium sp. and Prevalence of geoA-Like Genes in a Drinking Water Reservoir. Appl. Environ. Microbiol. 2007, 73, 6988-6993. [CrossRef]

25. Smith, J.L.; Boyer, G.L.; Zimba, P.V. A review of cyanobacterial odorous and bioactive metabolites: Impacts and management alternatives in aquaculture. Aquaculture 2008, 280, 5-20. [CrossRef]

26. Bharanidharan, M.; Sivasubramanian, V.; Rama Raja Valli Nayagam, S. Evaluation of antioxidant and antimicrobial potential of cyanobacteria, Chroococcus turgidus (Kützing) Nägeli. Int. J. Curr. Microbiol. Appl. Sci. 2013, 2, 300-305.

27. Dong, H.-W.; Zhang, S.; Sun, W.-G.; Liu, Q.; Ibla, J.C.; Soriano, S.G.; Han, X.-H.; Liu, L.-X.; Li, M.-S.; Liu, J.-R. $\beta$-Ionone arrests cell cycle of gastric carcinoma cancer cells by a MAPK pathway. Arch. Toxicol. 2013, 87, 1797-1808. [CrossRef]

28. Ozaki, K.; Ohta, A.; Iwata, C.; Horikawa, A.; Tsuji, K.; Ito, E.; Ikai, Y.; Harada, K. Lysis of cyanobacteria with volatile organic compounds. Chemosphere 2008, 71, 1531-1538. [CrossRef]

29. Khairy, H.M.; El-Kassas, H.Y. Active Substance from Some Blue Green Algal Species Used as Antimicrobial Agents. Afr. J. Biotechnol. 2010, 9, 2789-2800. [CrossRef]

30. Kim, D.H.; Park, M.H.; Choi, Y.J.; Chung, K.W.; Park, C.H.; Jang, E.J.; An, H.J.; Yu, B.P.; Chung, H.Y. Molecular Study of Dietary Heptadecane for the Anti-Inflammatory Modulation of NF-kB in the Aged Kidney. PLoS ONE 2013, 8, e59316. [CrossRef]

31. Coates, R.C.; Podell, S.; Korobeynikov, A.; Lapidus, A.; Pevzner, P.; Sherman, D.H.; Allen, E.E.; Gerwick, L.; Gerwick, W.H. Characterization of Cyanobacterial Hydrocarbon Composition and Distribution of Biosynthetic Pathways. PLoS ONE 2014, 9, e85140. [CrossRef] [PubMed]

32. Gupta, C. A Biotechnological Approach to Microbial Based Perfumes and Flavours. J. Microbiol. Exp. $2015,2$. [CrossRef]

33. Juneja, A.; Ceballos, R.; Murthy, G. Effects of Environmental Factors and Nutrient Availability on the Biochemical Composition of Algae for Biofuels Production: A Review. Energies 2013, 6, 4607-4638. [CrossRef]

34. Johnson, P.W.; Sieburth, J.M. Chroococcoid cyanobacteria in the sea: A ubiquitous and diverse phototrophic biomass. Limnol. Oceanogr. 1979, 24, 928-935. [CrossRef]

35. Liu, X.; Sheng, J.; Curtiss, R., III. Fatty acid production in genetically modified cyanobacteria. Proc. Natl. Acad. Sci. USA 2011, 108, 6899-6904. [CrossRef]

36. McNeely, K.; Xu, Y.; Bennette, N.; Bryant, D.A.; Dismukes, G.C. Redirecting Reductant Flux into Hydrogen Production via Metabolic Engineering of Fermentative Carbon Metabolism in a Cyanobacterium. Appl. Environ. Microbiol. 2010, 76, 5032-5038. [CrossRef]

37. Shakeel, T.; Fatma, Z.; Fatma, T.; Yazdani, S.S. Heterogeneity of Alkane Chain Length in Freshwater and Marine Cyanobacteria. Front. Bioeng. Biotechnol. 2015, 3. [CrossRef]

38. Liu, A.; Zhu, T.; Lu, X.; Song, L. Hydrocarbon profiles and phylogenetic analyses of diversified cyanobacterial species. Appl. Energy 2013, 111, 383-393. [CrossRef]

39. Lea-Smith, D.J.; Biller, S.J.; Davey, M.P.; Cotton, C.A.R.; Perez Sepulveda, B.M.; Turchyn, A.V.; Scanlan, D.J.; Smith, A.G.; Chisholm, S.W.; Howe, C.J. Contribution of cyanobacterial alkane production to the ocean hydrocarbon cycle. Proc. Natl. Acad. Sci. USA 2015, 112, 13591-13596. [CrossRef] 
40. Head, I.M.; Jones, D.M.; Röling, W.F.M. Marine microorganisms make a meal of oil. Nat. Rev. Microbiol. 2006, 4, 173-182. [CrossRef]

41. Berla, B.M.; Saha, R.; Maranas, C.D.; Pakrasi, H.B. Cyanobacterial Alkanes Modulate Photosynthetic Cyclic Electron Flow to Assist Growth under Cold Stress. Sci. Rep. 2015, 5. [CrossRef] [PubMed]

42. Weather. Available online: https://weather.com/weather/today/1/0.03,-51.10?par=google (accessed on 11 March 2019).

43. Lea-Smith, D.J.; Ortiz-Suarez, M.L.; Lenn, T.; Nürnberg, D.J.; Baers, L.L.; Davey, M.P.; Parolini, L.; Huber, R.G.; Cotton, C.A.R.; Mastroianni, G.; et al. Hydrocarbons Are Essential for Optimal Cell Size, Division, and Growth of Cyanobacteria. Plant Physiol. 2016, 172, 1928-1940. [CrossRef] [PubMed]

44. Schirmer, A.; Rude, M.A.; Li, X.; Popova, E.; del Cardayre, S.B. Microbial Biosynthesis of Alkanes. Science 2010, 329, 559-562. [CrossRef] [PubMed]

45. Mendez-Perez, D.; Begemann, M.B.; Pfleger, B.F. Modular Synthase-Encoding Gene Involved in $\alpha$-Olefin Biosynthesis in Synechococcus sp. Strain PCC 7002. Appl. Environ. Microbiol. 2011, 77, 4264-4267. [CrossRef] [PubMed]

46. Mendez-Perez, D.; Herman, N.A.; Pfleger, B.F. A Desaturase Gene Involved in the Formation of 1,14-Nonadecadiene in Synechococcus sp. Strain PCC 7002. Appl. Environ. Microbiol. 2014, 80, 6073-6079. [CrossRef]

47. Peralta-Yahya, P.P.; Zhang, F.; del Cardayre, S.B.; Keasling, J.D. Microbial engineering for the production of advanced biofuels. Nature 2012, 488, 320-328. [CrossRef]

48. Ozdemir, G.; Ulku Karabay, N.; Dalay, M.C.; Pazarbasi, B. Antibacterial activity of volatile component and various extracts of Spirulina platensis. Phytother. Res. 2004, 18, 754-757. [CrossRef]

49. Rao, A.G.; Reddy, D.D.R.; Krishnaiah, K.; Beevor, P.S.; Cork, A.; Hall, D.R. Identification and field optimization of the female sex pheromone of the rice leaf folder, Cnaphalocrocis medinalis in India. Entomol. Exp. Appl. 1995, 74, 195-200. [CrossRef]

50. Tengö, J.; Hefetz, A.; Bertsch, A.; Schmitt, U.; Lübke, G.; Francke, W. Species specificity and complexity of Dufour's gland secretion of bumble bees. Comp. Biochem. Physiol. Part B Comp. Biochem. 1991, 99, 641-646. [CrossRef]

51. Tengö, J.; Sick, M.; Ayasse, M.; Engels, W.; Svensson, B.G.; Lübke, G.; Francke, W. Species specificity of Dufour's gland morphology and volatile secretions in kleptoparasitic Sphecodes bees (Hymenoptera: Halictidae). Biochem. Syst. Ecol. 1992, 20, 351-362. [CrossRef]

52. Arn, H.; Rauscher, S.; Guerin, P.; Buser, H.-R. Sex pheromone blends of three tortricid pests in European vineyards. Agric. Ecosyst. Environ. 1988, 21, 111-117. [CrossRef]

53. Weatherston, J.; Tyrrell, D.; Percy, J.E. Long chain alcohol acetates in the defensive secretion of the millipede Blaniulus guttulatus. Chem. Phys. Lipids 1971, 7, 98-100. [CrossRef]

54. Sugawara, F.; Kobayashi, A.; Yamashita, K.; Matsuda, K. Identification of Octadecyl Acetate and (Z)-11 -Eicosenyl Acetate, Major Components of the Defensive Secretion of Gastrophysa atroceanea Motschulsky. Agric. Biol. Chem. 1978, 42, 687-688. [CrossRef]

55. Ramdani, M.; Bouchaala, M.; Lograda, T.; Chalard, P.; Figueredo, G. Chemical Composition, Antibacterial Activity and Chromosome Number of Helichrysum lacteum, Endemic from Algeria. Int. J. Pharma Res. Health Sci. 2016, 5, 1539-1545. [CrossRef]

56. El-Hawary, S.S.; Mohammed, R.; El-Din, M.; Awad, G. Influence of Cultivar Type of Strawberry Fruits on Its Volatile Constituents. J. Biol. Agric. Healthc. 2015, 5, 34-45.

57. Masuda, A.; Mori, K.; Miyazawa, M. Comparative analysis of volatile compounds from corms of Crocus sativus and C. vernus. Chem. Nat. Compd. 2012, 48,319-321. [CrossRef]

58. Hamdan, D.; El-Shazly, A. The Chemical Costituents of Egyptian Citrus Species. An Examination of The Volatile Oil and Light Petrolum Fraction of Rough Lemon (Citrus Jambahiri Lush.) Leaf. Eur. Sci. J. 2014, 10, $94-115$.

59. Dresow, J.F.; Böhm, H. The influence of volatile compounds of the flavour of raw, boiled and baked potatoes: Impact of agricultural measures on the volatile components. VTI Agric. For. Res. 2009, 4, 309-338.

60. Alaei, S.; Khosh-Khui, M.; Kobraee, S.; Zaji, B. Effect of different salinity levels on essential oil content and composition of Dracocephalum moldavica. Agric. Commun. 2014, 2, 42-46.

61. War, A.R.; Sharma, H.C.; Paulraj, M.G.; War, M.Y.; Ignacimuthu, S. Herbivore induced plant volatiles: Their role in plant defense for pest management. Plant Signal. Behav. 2011, 6, 1973-1978. [CrossRef]

62. Open Data Soft. Available online: https://www.opendatasoft.com/ (accessed on 26 April 2018). 
63. EWG's Skin Deep Database. Available online: https://www.ewg.org/skindeep/\#.WuGr7S7wbIU (accessed on 26 April 2018).

64. Rejmankova, E.; Higashi, R.M.; Roberts, D.R.; Lege, M.; Andre, R.G. The use of Solid Phase MicroExtraction (SPME) devices in analysis for potential mosquito oviposition attractant chemicals from cyanobacterial mats. Aquat. Ecol. 2000, 34, 413-420. [CrossRef]

65. Souto, R.N.P. Inventário da fauna culicidiana (Diptera:Culicidae) nas ressacas do Lago do Curralinho e da Lagoa dos Índios, Macapá, Amapá, Brasil. In Diagnóstico de ressacas do Estado do Amapá: Bacias do Igarapé da Fortaleza e do Rio Curiaú, 1st ed.; IEPA: Macapá, Brazil, 2003.

66. Modler, R.F.; Gubler, R.; Inoguchi, Y. APAG/CEFIC annual statistical data; detergent alcohols total consumption, year 2004. In Chemical Economics Handbook Marketing Research Report, Detergent Alcohols, Household Detergents and Their Raw Materials; SRI International: Menlo Park, CA, USA, 2004.

67. Rupilius, W.; Ahmad, S. The Changing World of Oleochemicals. Palm Oil Dev. 2006, 44, 15-28.

68. OECD. SIDS Initial Assessment Report for SIAM 22, Paris, France, 18-21 April 2006. TOME 1: SIAR. Category: Long Chain Alcohols, 294; OECD: Paris, France, 2006.

69. Kubo, I.; Muroi, H.; Kubo, A. Naturally Occurring Antiacne Agents. J. Nat. Prod. 1994, 57, 9-17. [CrossRef] [PubMed]

70. Venkatesan, K.; Srinivasan, K.V. A Novel Stereoselective Synthesis of Pachastrissamine (Jaspine B) Starting From 1-Pentadecanol. Tetrahedron Asymmetry 2008, 19, 209-215. [CrossRef]

71. George, S.; Suryavanshi, G.; Sudalai, A. A short enantioselective synthesis of guggultetrol, a naturally occurring lipid. Tetrahedron Asymmetry 2010, 21, 558-561. [CrossRef]

72. Yao, L.; Qi, F.; Tan, X.; Lu, X. Improved production of fatty alcohols in cyanobacteria by metabolic engineering. Biotechnol. Biofuels 2014, 7, 94. [CrossRef]

73. Tan, X.; Yao, L.; Gao, Q.; Wang, W.; Qi, F.; Lu, X. Photosynthesis driven conversion of carbon dioxide to fatty alcohols and hydrocarbons in cyanobacteria. Metab. Eng. 2011, 13, 169-176. [CrossRef]

74. Shih, P.M.; Wu, D.; Latifi, A.; Axen, S.D.; Fewer, D.P.; Talla, E.; Calteau, A.; Cai, F.; Tandeau de Marsac, N.; Rippka, R.; et al. Improving the coverage of the cyanobacterial phylum using diversity-driven genome sequencing. Proc. Natl. Acad. Sci. USA 2013, 110, 1053-1058. [CrossRef]

75. Nordling, E.; Jörnvall,H.; Persson, B. Medium-chain dehydrogenases/reductases (MDR): Family characterizations including genome comparisons and active site modelling. Eur. J. Biochem. 2002, 269, 4267-4276. [CrossRef]

76. De Smidt, O.; du Preez, J.C.; Albertyn, J. The alcohol dehydrogenases of Saccharomyces cerevisiae: A comprehensive review. FEMS Yeast Res. 2008, 8, 967-978. [CrossRef]

77. de Oliveira, D.T.; Vasconcelos, C.T.; Feitosa, A.M.; Aboim, J.B.; de Oliveira, A.D.; Xavier, L.P.; Santos, A.S.; Gonçalves, E.C.; da Rocha Filho, G.N.; do Nascimento, L.A. Lipid profile analysis of three new Amazonian cyanobacteria as potential sources of biodiesel. Fuel 2018, 234, 785-788. [CrossRef]

78. Aboim, J.B.; Oliveira, D.; Ferreira, J.E.; Siqueira, A.S.; Dall'Agnol, L.T.; Rocha Filho, G.N.; Gonçalves, E.C.; Nascimento, L.A. Determination of biodiesel properties based on a fatty acid profile of eight Amazon cyanobacterial strains grown in two different culture media. RSC Adv. 2016, 6, 109751-109758. [CrossRef]

79. Vidal, R.; Lopez-Maury, L.; Guerrero, M.G.; Florencio, F.J. Characterization of an Alcohol Dehydrogenase from the Cyanobacterium Synechocystis sp. Strain PCC 6803 That Responds to Environmental Stress Conditions via the Hik34-Rre1 Two-Component System. J. Bacteriol. 2009, 191, 4383-4391. [CrossRef] [PubMed]

80. Kaiser, B.K.; Carleton, M.; Hickman, J.W.; Miller, C.; Lawson, D.; Budde, M.; Warrener, P.; Paredes, A.; Mullapudi, S.; Navarro, P.; et al. Fatty Aldehydes in Cyanobacteria Are a Metabolically Flexible Precursor for a Diversity of Biofuel Products. PLoS ONE 2013, 8, e58307. [CrossRef]

81. Martins, R.F.; Ramos, M.F.; Herfindal, L.; Sousa, J.A.; Skaerven, K.; Vasconcelos, V.M. Antimicrobial and cytotoxic assessment of marine cyanobacteria Synechocystis and Synechococcus. Mar. Drugs 2008, 6, 1-11. [CrossRef]

82. Delcour, A.H. Outer membrane permeability and antibiotic resistance. Biochim. Biophys. Acta Proteins Proteom. 2009, 1794, 808-816. [CrossRef]

83. Nikaido, H. Molecular Basis of Bacterial Outer Membrane Permeability Revisited. Microbiol. Mol. Biol. Rev. 2003, 67, 593-656. [CrossRef]

84. Martin, J.F. Phosphate Control of the Biosynthesis of Antibiotics and Other Secondary Metabolites Is Mediated by the PhoR-PhoP System: An Unfinished Story. J. Bacteriol. 2004, 186, 5197-5201. [CrossRef] 
85. Guimarães, P.I.; Leão, T.F.; de Melo, A.G.C.; Ramos, R.T.J.; Silva, A.; Fiore, M.F.; Schneider, M.P.C. Draft Genome Sequence of the Picocyanobacterium Synechococcus sp. Strain GFB01, Isolated from a Freshwater Lagoon in the Brazilian Amazon. Genome Announc. 2015, 3, e00876-15. [CrossRef]

86. Rippka, R.; Deruelles, J.; Waterbury, J.B.; Herdman, M.; Stanier, R.Y. Generic Assignments, Strain Histories and Properties of Pure Cultures of Cyanobacteria. Microbiology 1979, 111, 1-61. [CrossRef]

87. Vandendool, H.; Kratz, P.D. A Generalization of The Retention Index System Including Linear Temperature Programmed Gas-Liquid Partition Chromatography. J. Chromatogr. 1963, 11, 463-471. [CrossRef]

Sample Availability: Samples of the extracts are available from the authors.

(C) 2020 by the authors. Licensee MDPI, Basel, Switzerland. This article is an open access article distributed under the terms and conditions of the Creative Commons Attribution (CC BY) license (http://creativecommons.org/licenses/by/4.0/). 